\title{
Daily Changes of Infections by Pythium ultimum After a Nutrient Impulse in Organic Versus Conventional Soils
}

\author{
Miaomiao He, Wenjun Ma, Guangming Tian, Wim Blok, Anna Khodzaeva, \\ Vladimir V. Zelenev, Alexander M. Semenov, and Ariena H. C. van Bruggen
}

First author: Department of Life and Environmental Science, Hangzhou Normal University, Hangzhou 310036, China, and Department of Environment and Resource, Zhejiang University, Hangzhou 310029, China; second author: Magazine, Chang'an University, Xi'an, Shaanxi, China, and College of Resources and Environment, China Agricultural University, Beijing, China; third author: Department of Environment and Resource, Zhejiang University, Hangzhou 310029, China; fourth author: Department of Plant Sciences, Biological Farming Systems Group, Wageningen University, P.O. Box 563, 6700 AN Wageningen, The Netherlands; fifth author: Institute of Physical-Chemical and Biological Problems in Soil Science of RAS, Institutskaya ul., 2, 142290, Pushchino, Moscow region, Russia; sixth author: Laboratory for Microorganism Cultivation Processes, Institute of Vaccines and Serums, Russian Academy of Medical Sciences, Malyi Kazennyi per., 5a, 103064 Moscow, Russia; seventh author: Department of Microbiology, Biological Faculty, Moscow State University, 119899 Vorob'evy Gory, Moscow, Russia; and eighth author: Department of Plant Pathology, University of Florida, P.O. Box 110680, Gainesville 32611-0680, and Department of Plant Sciences, Biological Farming Systems Group, Wageningen University, The Netherlands.

Accepted for publication 6 February 2010.

\begin{abstract}
He, M., Ma, W., Tian, G., Blok, W., Khodzaeva, A., Zelenev, V. V., Semenov, A. M., and van Bruggen, A. H. C. 2010. Daily changes of infections by Pythium ultimum after a nutrient impulse in organic versus conventional soils. Phytopathology 100:593-600.

Bacterial populations (CFU) have been shown to oscillate in wavelike patterns after nutrient impulses in previous studies. The amplitudes and periods of oscillations could possibly be used as indicators of soil health analogous to the stability and resilience of biological populations widely accepted as indicators for ecosystem health. Limited plant and animal disease outbreaks can also be viewed as a manifestation of a healthy soil ecosystem. Two pot experiments were carried out to verify whether damping-off of beet seedlings by Pythium ultimum, measured as area under the disease progress curve (AUDPC), fluctuated over time after incorporation of organic materials into organic versus conventional soils, and to investigate whether daily dynamics of AUDPCs were linked to the dynamics of microbial populations and chemical parameters. AUDPCs oscillated significantly over time when Pythium bioassays were initiated daily after addition of ground grass and clover shoots (GC) into unplanted soils. Similar oscillations with significant harmonics of AUDPC were also

amplitudes than in GC-amended soils. The AUDPC harmonics in amended soils had periods similar to those of CFU of copiotrophic bacteria. Cross-correlation analysis demonstrated that periodic fluctuations of P. ultimum infections (AUDPCs) did not coincide with those of copiotrophic CFU but were shifted in phase. It appears that competition or antagonism from some fast-growing bacteria influenced pathogen infections, because these bacterial populations were growing and dying. Soil chemical variables, including $\mathrm{pH}$, dissolved organic carbon, and $\mathrm{NO}_{3}{ }^{-}-\mathrm{N}$, and $\mathrm{NH}_{4}{ }^{+}-\mathrm{N}$ contents, changed significantly in the initial 7 days after a nutrient impulse into soils. These changes were cross-correlated with copiotrophic CFU with time lags of $\approx 1$ to 2 days but were seldom associated with daily changes in AUDPCs. Organically managed soils always had lower AUDPC ratios of amended to nonamended treatments, indicating that organic materials showed stronger suppressive abilities to $P$. ultimum in organic than in conventional soils. The oscillations in AUDPCs and copiotrophic CFU in amended organic soil also had smaller amplitudes than in amended conventional soil. These results suggested that organically managed soils had a greater resistance and resilience to the disturbance of the amendments and, therefore, could be considered healthier than conventionally managed soils.
\end{abstract} observed in composted manure $(\mathrm{CM})$-amended soils but with smaller
Wavelike oscillations in microbial populations after a disturbance had been demonstrated several times $(46,48)$. The amplitude and period of these regular oscillations were proposed to be an indicator of stability and resilience of soil ecosystems, which was suggested as a new approach for quantifying the health status of a soil $(37,39)$. Experiments with $\gamma$-irradiated and nonirradiated soils showed that bacteria populations (CFU) oscillated in a wavelike pattern over time, and harmonics analysis demonstrated that $\gamma$-irradiated soil had larger amplitudes and periods of wavelike oscillations in microbial populations (i.e., lower stability and resilience) than nonirradiated soil after incorporation of grass and clover shoots, suggesting that nonirradiated soil is healthier (45).

Corresponding author: A. H. C. van Bruggen

E-mail address: ahcvanbruggen@ufl.edu

doi:10.1094/PHYTO-100-6-0593

(C) 2010 The American Phytopathological Society
Larger amplitudes of oscillations in microbial populations were also observed in a fallow soil than in a cover-cropped soil after addition of the same amount of cover crop plant material, implying that cover-cropped soils may be healthier than fallow soils $(37,38)$.

A healthy soil ecosystem is frequently associated with limited plant and animal disease outbreaks (30). A higher microbial diversity in healthy soils can play a role in plant pathogen suppression and affect internal nutrient cycling $(12,37)$. We hypothesize that infections by plant pathogens in perturbed soils have wavelike patterns over time with smaller amplitudes in healthier than in less healthy soils, similar to the reduced amplitudes of microbial oscillations in healthier soils. In previous experiments with wheat roots, harmonics analysis showed that infections by root pathogens fluctuated along the wheat roots (40). Furthermore, oscillations of Pythium spp. infections were positively correlated with oscillations in copiotrophic bacteria at a lag of $6 \mathrm{~cm}$ along the roots. Temporal wavelike dynamics could be deduced from ob- 
served spatial wavelike distributions (47). Indeed, in a preliminary study with sampling intervals of 7 days, temporal fluctuations of Pythium spp. infections on tomato seedlings followed copiotrophic bacterial populations at a lag of $\approx 6$ days in fallowed and cover-cropped soils after incorporation of vetch-oat cover crop shoots $(37,38)$. However, frequent and detailed observations of plant infections after a disturbance were not made, so that harmonics analysis could not be used to distinguish significant oscillations in those experiments.

The occurrence of regular waves in bacterial populations might be due to the growth-death cycle of microorganisms and succession of different microbial species in response to an impulse of nutrients $(39,42)$. Such a succession in bacterial communities occurred within one waxing and waning phase of an oscillation rather than between oscillations, as demonstrated by changes in microbial composition detected by denaturing gradient gel electrophoresis $(8,42)$. The growth-death cycles of bacteria and the successions of microbial communities might result in alternating levels of competition between particular bacteria and plant pathogens, resulting in oscillations in disease incidence.

Recently, many researchers have shown effects of organic amendments on plant disease incidence in soils $(3,20,25,26,29$, 35 ), and various investigations have been carried out on changes in soil chemical and microbial properties after disturbances $(6,11,13,14,28,36)$. However, the daily dynamics of pathogen infections in soil after a disturbance have seldom been explored (17), and their correlations with soil microbial populations and chemical properties not at all.

Our research was aimed at understanding the short-term dynamics of infections by the root pathogen Pythium ultimum in relation to the daily changes of bacterial populations and chemical properties after incorporation of organic materials into different soils under controlled environment conditions. Specific objectives were to investigate whether (i) there are temporal wavelike patterns in infections by $P$. ultimum after a nutrient impulse into soils, (ii) such patterns correlate with the wavelike fluctuations of microbial populations after a nutrient impulse in soil, and (iii) the daily changes of chemical properties relate to short-term fluctuations in infections by $P$. ultimum. Experiments were conducted with two kinds of organic amendments in organically and conventionally managed soils, allowing us to investigate an additional aim: (iv) to compare the daily changes of damping-off, soil microbial populations, and chemical properties between two differently managed soils amended with different organic materials.

\section{MATERIALS AND METHODS}

Soil. Experiments were conducted with two pairs of sandy soils collected from organically managed fields in the Droevendaal experimental farm, which had been organic for 7 years, and neighboring conventional fields of Unifarm, Wageningen UR, The Netherlands. The organic fields had received cover-crop materials and composted cattle manure and cattle slurry to fertilize the crops, while the conventional fields had received only inorganic fertilizers. Pesticides had been used in the conventional fields only. For the experiment in spring 2007, both the organic and conventional soils were from fields planted to maize (Zea mays L.) in 2006, and maize residues were still visible. For the experiment in the summer of 2007 , two soils were collected from organic and conventional fields that had maize crops at the time of sampling. Soil was taken to a depth of $15 \mathrm{~cm}$ in each field. After collection, the soils were sieved through a screen with 4-mm mesh and stored in a controlled environment room at $20^{\circ} \mathrm{C}$ until the start of the experiments. The moisture contents of the soils were measured immediately. General soil properties were determined after air drying (Table 1).

Soil chemical analyses. Soil samples were dried, ground, and suspended in $\mathrm{CaCl}_{2}$. Soil extracts in $\mathrm{CaCl}_{2}$ were analyzed for $\mathrm{pH}$, $\mathrm{NO}_{3}-\mathrm{N}, \mathrm{NH}_{4}-\mathrm{N}$, total soluble $\mathrm{N}$ content, and dissolved organic carbon (DOC) content. The concentrations of $\mathrm{NO}_{3}-\mathrm{N}$ and $\mathrm{NH}_{4}-\mathrm{N}$ were determined by an automatic inorganic nitrogen analyzer (Autoanalyzer II system; Technicon Instruments, St. Dennis, France). The contents of DOC were measured by a TOC Analyzer (Shimadzu, Japan). The moisture content of the fresh soils was determined with $\approx 10$-g samples on a Mettler LJ16 moisture content analyzer (Mettler Toledo International Inc., OH).

Experimental design. The experiments were carried out from 23 May to 12 June and from 2 to 22 August 2007. Both experiments consisted of two series of PVC pots (diameter, $10.2 \mathrm{~cm}$ and depth, $25 \mathrm{~cm}$ ) containing nonamended soil or soil mixed with $1 \%$ (wt/wt, by dry weight) of dry and milled amendments. A mixture of grass and clover (GC) was the amendment for the spring experiment. Grass and clover were cut from a field at Wageningen University and mixed in a 1:1 ratio based on fresh weight. The average carbon and nitrogen contents for the GC mixture were 41.6 and $2.6 \%$, respectively (based on dry weights). Composted cattle manure (CM), consisting of cattle dung mixed with straw, was the amendment for the summer experiment. It was collected from a heap at the Droevendaal farm and dried and milled before use. The carbon and nitrogen contents of CM based on dry weights were 29.76 and $2.51 \%$, respectively. The day before the start of each experiment (day 0), predetermined amounts of water were added to the soils to reach a water-filled pore space of $25 \%$ and an air-filled pore space of $20 \%$ in the pots, corresponding to $14.6 \%$ of moisture value in both experiments (assuming a soil particle density of $2.65 \mathrm{mg} \mathrm{m}^{-3}$ and depth of $20 \mathrm{~cm}$ ). Inoculum of $P$. ultimum was mixed into all soils at a rate of $0.1 \%(\mathrm{vol} / \mathrm{vol})$ on day 0 to overwhelm the low level of $P$. ultimum naturally occurring in the soils (based on a preliminary experiment with the same soils). Fresh inoculum of $P$. ultimum was prepared in a soil-oatmeal culture (44).

The final C:N ratio of amended soil ranged from 15.97 to 17.75 in the spring experiment and 13.04 to 15.77 in the summer experiment. The soils with or without amendments were filled into the PVC pots to a height of $20 \mathrm{~cm}$. To prevent water losses but allow air exchange, the pots were covered with a thin plastic film. The pots with the different treatments (soil management type and with or without amendment) were randomized in three blocks in a controlled environment room at $20^{\circ} \mathrm{C}$ and incubated for 20 days.

Three pots of each treatment (one per block) were collected every day. All soil from one pot was mixed first; then, subsamples

TABLE 1. Characteristics of soils collected from organically and conventionally managed fields in this study ${ }^{\mathrm{a}}$

\begin{tabular}{|c|c|c|c|c|}
\hline \multirow[b]{2}{*}{ Soil characteristics } & \multicolumn{2}{|c|}{ Spring 2007} & \multicolumn{2}{|c|}{ Summer 2007} \\
\hline & Organic soil & Conventional soil & Organic soil & Conventional soil \\
\hline Sand content $(\%)$ & $92.78 \pm 1.31$ & $93.24 \pm 1.00$ & $89.30 \pm 0.06$ & $91.17 \pm 0.54$ \\
\hline Silt content $(\%)$ & $4.77 \pm 0.19$ & $4.51 \pm 0.23$ & $7.00 \pm 0.62$ & $6.13 \pm 0.17$ \\
\hline Clay content $(\%)$ & $2.45 \pm 0.27$ & $2.25 \pm 0.18$ & $3.70 \pm 0.09$ & $2.70 \pm 0.20$ \\
\hline $\mathrm{pH}\left(\mathrm{CaCl}_{2}\right)$ & $5.59 \pm 0.03$ & $5.55 \pm 0.04$ & $5.37 \pm 0.01$ & $5.51 \pm 0.05$ \\
\hline Organic matter content $(\%)$ & $2.85 \pm 0.01$ & $2.25 \pm 0.02$ & $3.03 \pm 0.01$ & $1.91 \pm 0.01$ \\
\hline Total $\mathrm{N}$ content $\left(\mathrm{mg} \mathrm{kg}^{-1}\right)$ & $1,039 \pm 26$ & $806 \pm 30$ & $1,115 \pm 41$ & $662 \pm 19$ \\
\hline
\end{tabular}

a Values are means \pm standard deviations $(n=3)$. 
were taken for determination of soil moisture, $\mathrm{pH}$, dissolved organic carbon (DOC), $\mathrm{NO}_{3}-\mathrm{N}$, and $\mathrm{NH}_{4}-\mathrm{N}$ contents as described above for determination of copiotrophic bacterial populations (CFU) and for P. ultimum bioassays. Thus, separate bioassays for P. ultimum disease development and determination of area under the disease progress curves (AUDPCs) were initiated daily.

Dilution plating of bacteria from soil. Soil (10 g) was added to $90 \mathrm{ml}$ of sterile deionized water and shaken on a rotary shaker for $15 \mathrm{~min}$ at $300 \mathrm{rpm}$. The suspension was sonicated for $5 \mathrm{~min}$ in an ultrasonic bath. Then, 10-fold serial dilutions were made. For amended soils, $50 \mu \mathrm{l}$ of $10^{-5}$ and $10^{-6}$ suspensions were plated onto triplicate plates with high carbon $(\mathrm{C}$ at $1,000 \mathrm{ppm})$ media for copiotrophic bacteria, to determine CFU per gram of dry soil as described previously $(32,42)$. For unamended soils, $50 \mu \mathrm{l}$ of $10^{-4}$ and $10^{-5}$ suspensions were plated. The agar medium contained $0.5 \mathrm{~g}$ of $\mathrm{MgSO}_{4} \cdot 7 \mathrm{H}_{2} \mathrm{O}, 0.5 \mathrm{~g}$ of $\mathrm{KNO}_{3}, 1.3 \mathrm{~g}$ of $\mathrm{K}_{2} \mathrm{HPO}_{4} \cdot 3 \mathrm{H}_{2} \mathrm{O}$, $0.06 \mathrm{~g}$ of $\mathrm{Ca}\left(\mathrm{NO}_{3}\right)_{2} \cdot 4 \mathrm{H}_{2} \mathrm{O}, 2.5 \mathrm{~g}$ of glucose, $0.2 \mathrm{~g}$ of enzymatic casein hydrolysate, and $15.0 \mathrm{~g}$ of Bacto Agar per liter, plus sterile cycloheximide at $100 \mathrm{ppm}$. The total amount of carbon available for bacterial consumption was estimated at $1,100 \mathrm{mg} \mathrm{liter}^{-1}$ of medium. Bacteria colonies were counted after $48 \mathrm{~h}$ of incubation at $25^{\circ} \mathrm{C}$.

Bioassays for root pathogen infection. The $P$. ultimum bioassays were carried out in a controlled environment chamber at $20^{\circ} \mathrm{C}$ (16-h day and 8-h night regime). For both main experiments, 30 sugar beet (cv. Anastasia) seeds were sown daily in one pot (0.6 liter) per soil sample. On days 14, 18, and 21 after sowing the seed, the numbers of healthy seedlings were scored and the numbers of completely damped-off or dead plants (30 minus the number of healthy seedlings) were calculated. In this disease assay, we used the AUDPC (2) to express the incidence of seedlings infected by P. ultimum over time. Roots of damped-off seedlings were observed for symptoms and plated onto water agar to check for the presence of P. ultimum.

Statistical analysis. CFU and AUDPC data were compared by one-sided paired $t$ tests among treatments and between experiments using SPSS 15.0 for Windows. To detect the presence of significant wavelike oscillations for CFU and AUDPC of Pythium spp. infections, harmonics analysis (also called Fourier analysis) was conducted on individual data series ( 24 series for each of the experiments) according to Jenkins and Watts (22) with modifications of Gorbenko and Kryshev (15). The data were detrended by linear regression and smoothed using Hann's three-point window before harmonics analysis (33). Significant harmonics and their period, phase, and amplitude were determined at the 0.05 significance level. Cross-correlation functions at 0.05 significance levels were calculated for all variables with SPSS 15.0 for Windows.

\section{RESULTS}

Damping-off. Damping-off was caused by $P$. ultimum based on typical symptoms on the root tips and base and on isolations of the pathogen. There were fluctuations in AUDPC for all series of pots, with similar fluctuations for the three blocks. Because the fluctuations were not exactly synchronous, mean values would obscure any significant oscillations. Therefore, the results of single blocks are presented rather than averages of the three blocks per experiment. The AUDPC of damping-off of sugar beet seedlings decreased immediately after incorporation of GC into both organic and conventional soils but increased after 1 day, with the first peak on the third day and the second peak on the fifth day (Fig. 1A). The first peak in AUDPC in GC-amended organic soil was much smaller than the second one, whereas the GC-amended conventional soil had the larger peak on the third day. These two peaks were followed by three weak but significant fluctuations $(t$ test, $P<0.05)$. In the summer experiment, the AUDPC in CMtreated conventional soil increased immediately and reached the first peak after 2 days, dropped, and rose again with the second peak after 5 days (Fig. 1B). These initial two peaks were followed by continuous oscillations. Organic soil had lower AUDPC values than conventional soil after addition of manure. The first remarkable peak of AUDPC in CM-amended organic soil appeared on the third day, and AUDPC values continued to fluctuate with two gentler oscillations. The mean standard errors (three blocks) for AUDPC were 15.91 and 16.37 for GC-amended organic soil and conventional soil, respectively, and 12.41 and 9.31 for CMamended organic soil and conventional soil, respectively. These mean errors between replications were negligible compared with the changes over time (Fig. 1).

The data of AUDPC ratio in amended soils to nonamended soils could represent suppressive abilities of organic materials to plant disease. In both experiments, the AUDPC data in control series had minor variations over time, so that the AUDPC ratio had oscillations similar to the AUDPC in amended soils and fluctuated around 1 (Fig. 1). More than $70 \%$ of the AUDPC ratio data were $<1$ in both amended organic soils, whereas $<50 \%$ of these data in both amended conventional soils were $<1$, indicating that organic materials showed stronger inhibitory abilities to plant disease in organic soils than in conventional soils, especially after 7 days. The mean standard errors for AUDPC ratios in the spring experiment were 0.14 and 0.18 for organic and conventional soil, respectively, and 0.13 and 0.11 in organic and conventional soil, respectively, for the summer experiment. Again, these mean errors for the replications were small compared with the changes over time.

Harmonics analysis of detrended and smoothed AUDPC data demonstrated that there were remarkable wavelike patterns with one and two significant harmonics in organic and conventional soils, respectively, after incorporation of GC (Fig. 2; Table 2).
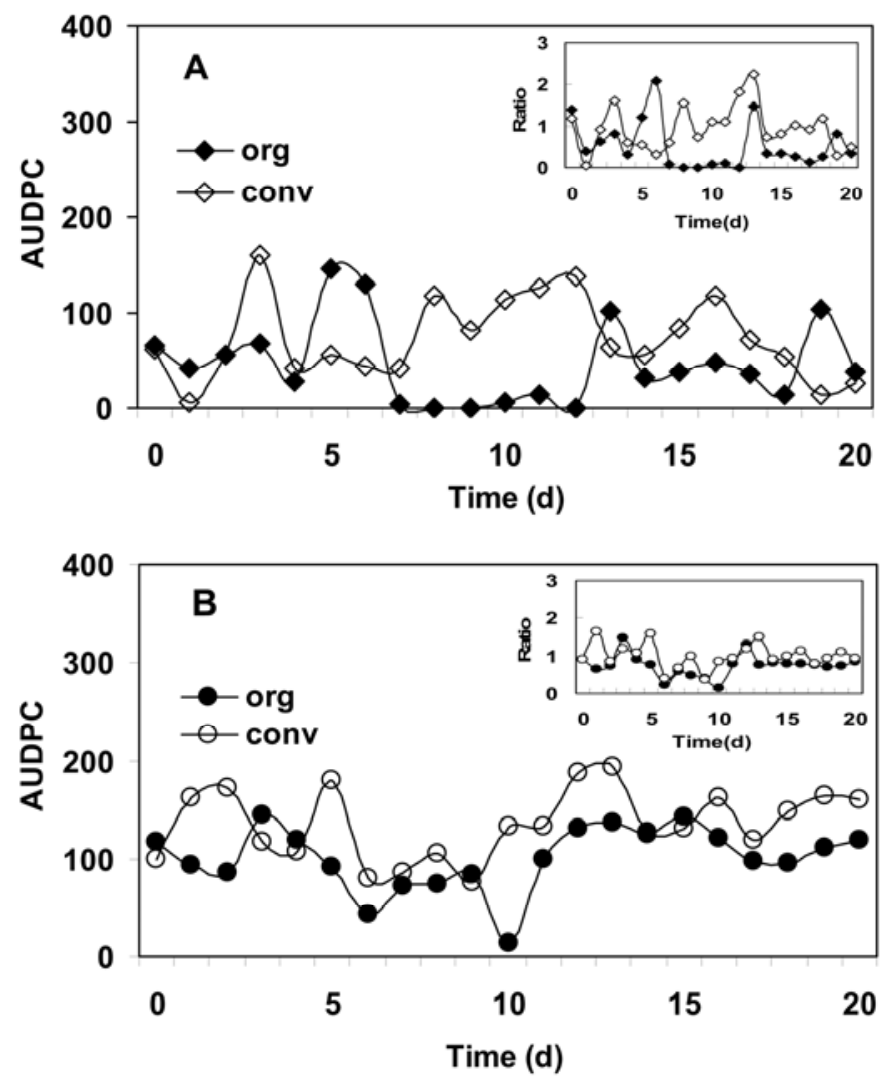

Fig. 1. Daily changes in area under the disease progress curve (AUDPC) of damping-off (Pythium ultimum) on sugar beet seedlings in organic (org) and conventional (conv) soils after incorporation of $\mathbf{A}$, grass-clover or $\mathbf{B}$, composted manure; figures in the top right corners were ratio of AUDPC in amended soils to nonamended soils over time. 
These harmonics contributed 33.5 and $78.99 \%$, respectively, to the observed variation in AUDPC. In the summer experiment, the first and second harmonics were significant in both CM-amended organic and conventional soils, accounting for 65.51 and $74.99 \%$ of the variation, respectively (Table 2). The amplitudes in the GCamended soils were much greater than in CM-amended soils, probably because GC had more readily available carbon sources than CM.

Bacterial CFU. Similar to the fluctuations in AUDPC, there were fluctuations in CFU for all three blocks, which were not exactly synchronous. Therefore, the results of single blocks are presented rather than averages of the three blocks. The numbers of copiotrophic CFU in amended soils were significantly $(P<$ 0.001) higher than in nonamended soils (Fig. 3). The conventional soils always had the greater fluctuations after incorporation of organic materials. In the spring experiment, CFU increased immediately after incorporation of plant residues with the first peak after 1 day in both amended soils, which was observed 2 days earlier than the first peak of AUDPC (Fig. 3A). In the following days, the bacterial populations continued to fluctuate with weak oscillations in GC-amended organic soil, whereas CFU in GC-amended conventional soil fluctuated at similar intervals of 4 to 5 days and reached high levels again after 9 days. These peaks appeared 1 to 2 days ahead of the AUDPC peaks. Copiotrophic CFU in CM-treated soils increased more slowly than in GC-amended soils and fluctuated with weaker oscillations (Fig. 3B). The first peak of CFU in both CM-amended soils occurred after a monotonous increase for 3 days. After the first peak, the CFU fluctuated with several peaks, and these peaks were observed 1 to 2 days and 2 to 3 days behind AUDPC peaks in CMamended conventional and organic soils, respectively. The mean standard errors for copiotrophic CFU were $10.73 \times 10^{6}$ and $7.47 \times$ $10^{6} \mathrm{~g}^{-1}$ of dry soil for GC-amended organic soil and conventional soil, respectively, and $3.64 \times 10^{6}$ and $5.36 \times 10^{6} \mathrm{~g}^{-1}$ of dry soil for CM-amended organic soil and conventional soil, respectively.

There were significant wavelike oscillations for daily changes of copiotrophic CFU (Fig. 2; Table 2). The harmonics for CFU data accounted for 42.4 and $56.14 \%$ of the variation in GC-
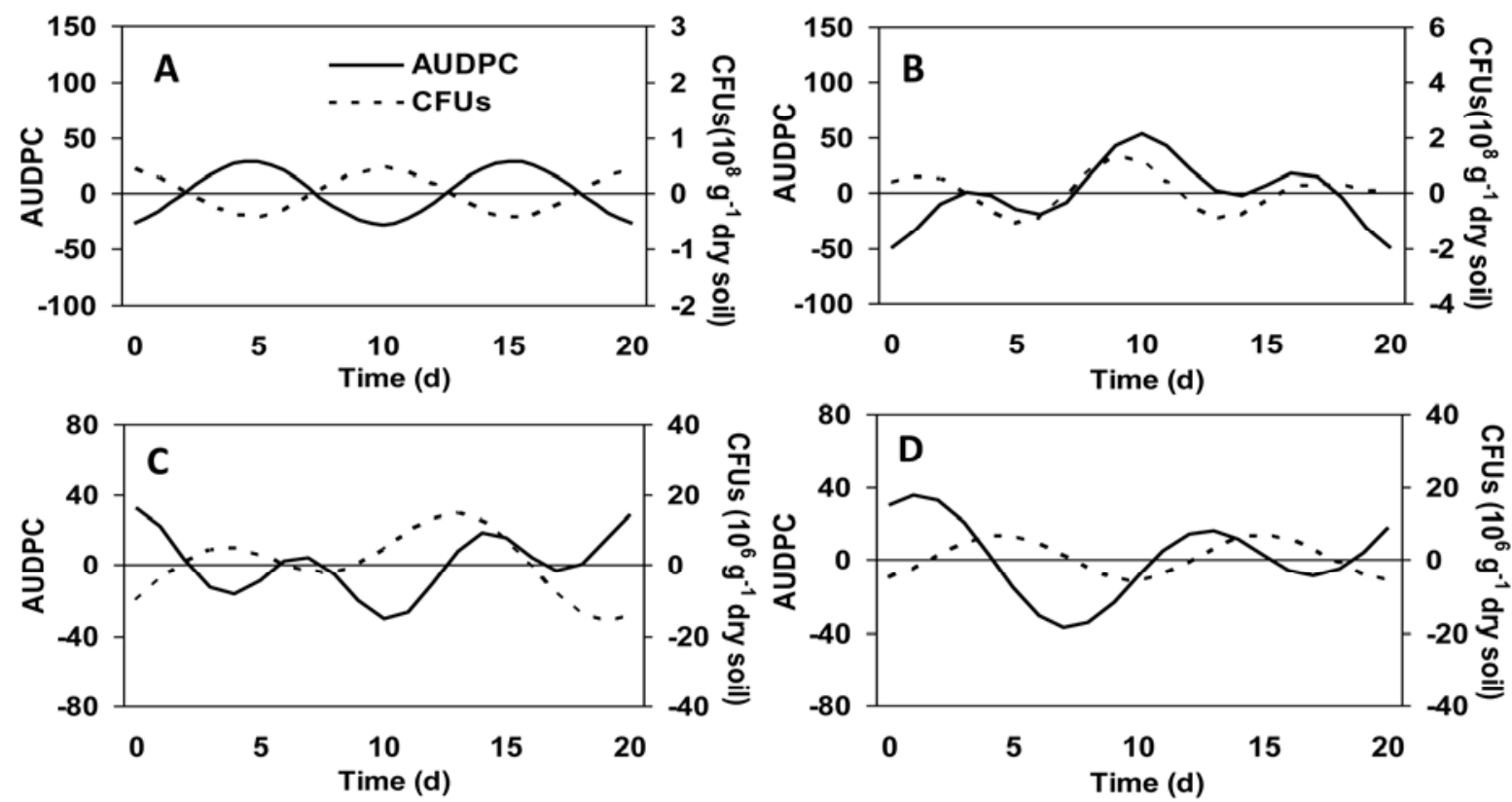

Fig. 2. Harmonic oscillations in area under the disease progress curve (AUDPC) of damping-off on sugar beet seedlings infected by Pythium ultimum and copiotrophic CFU/g of dry soil over time in A, grass-clover-amended organic soil; B, grass-clover-amended conventional soil; $\mathbf{C}$, composted-manure-amended organic soil; and $\mathbf{D}$, composted manure amended conventional soil.

TABLE 2. Characteristics of significant harmonics detected by harmonics analysis for daily dynamics of area under disease progress curve (AUDPC) of dampingoff of seedling infected by Pythium ultimum and CFU/g of dry soil in organic (org) and conventional (conv) soils after incorporations of grass-clover (GC) or composted manure $(\mathrm{CM})$

\begin{tabular}{|c|c|c|c|c|c|c|c|c|c|}
\hline Variable & Treatment & $\begin{array}{c}\text { Harmonic } \\
\text { no. }^{\mathrm{a}}\end{array}$ & Amplitude ${ }^{b}$ & $\begin{array}{l}\text { Phase } \\
\text { (days) }\end{array}$ & $\begin{array}{l}\text { Period } \\
\text { (days) }\end{array}$ & $\begin{array}{l}\text { Frequency } \\
\left(\text { days }^{-1}\right)\end{array}$ & $\begin{array}{c}\text { Contribution to } \\
\text { variance }(\%)\end{array}$ & $F$ estimated $^{\mathrm{c}}$ & $n$ \\
\hline \multirow[t]{3}{*}{ AUDPC } & Org-GC & 2 & 28.35 & 4.69 & 10.5 & 0.0952 & 33.5 & $3.35 *$ & 21 \\
\hline & Conv-GC & 1 & 30.73 & 10.88 & 21 & 0.0476 & 49.7 & $4.97 * *$ & 21 \\
\hline & & 3 & 23.60 & 2.86 & 7 & 0.1429 & 29.29 & $2.929 *$ & 21 \\
\hline \multirow[t]{3}{*}{$\mathrm{CFU}$} & Org-GC & 2 & $43.9 \times 10^{6}$ & -0.554 & 10.5 & 0.0952 & 42.4 & $4.24 * *$ & 21 \\
\hline & Conv-GC & 2 & $67.8 \times 10^{6}$ & -1.044 & 10.5 & 0.0952 & 29.91 & $2.991 *$ & 21 \\
\hline & & 3 & $63.5 \times 10^{6}$ & 2.140 & 7 & 0.1429 & 26.23 & $2.623^{*}$ & 21 \\
\hline \multirow[t]{4}{*}{ AUDPC } & Org-CM & 1 & 16.1 & -1.7 & 21 & 0.0476 & 30.01 & $3.001 *$ & 21 \\
\hline & & 2 & 17.5 & -0.08 & 10.5 & 0.0952 & 35.5 & $3.55^{* *}$ & 21 \\
\hline & Conv-CM & 1 & 17.4 & -1.59 & 21 & 0.0476 & 26.09 & $2.609 *$ & 21 \\
\hline & & 2 & 23.8 & 1.66 & 10.5 & 0.0952 & 48.9 & $4.89 * *$ & 21 \\
\hline \multirow[t]{3}{*}{$\mathrm{CFU}$} & Org-CM & 1 & $8.52 \times 10^{6}$ & 10.3 & 21 & 0.0476 & 32.3 & $3.23 *$ & 21 \\
\hline & & 2 & $8.93 \times 10^{6}$ & 2.95 & 10.5 & 0.0952 & 35.4 & $3.54 * *$ & 21 \\
\hline & Conv-CM & 2 & $8.39 \times 10^{6}$ & 4.45 & 10.5 & 0.0952 & 36 & $3.6^{* *}$ & 21 \\
\hline
\end{tabular}

a Number of oscillations.

${ }^{\mathrm{b}}$ Half of the distance between maximum and minimum in an oscillation.

c Significant levels: $*$ and $* *=0.10$ and 0.05 , respectively. 
amended organic and conventional soils, respectively, and 67.7 and $36 \%$ of the variation in CM-treated organic and conventional soils, respectively (Table 2). The periods and frequencies of oscillations in CFU were similar to the harmonics of AUDPC in each amended soil but the phases were shifted (Fig. 2).

Cross-correlation analysis (Table 3) demonstrated that the AUDPC data were positively correlated with copiotrophic CFU at a lag of 4 and 2 days in GC-amended organic and conventional soils, respectively. Similarly, AUDPC data in the summer experiment showed significant $(P<0.05)$ positive correlations with CFU; however, the correlations were observed when the AUDPC data were moved forward 3 and 2 days in CM-amended organic and conventional soils, respectively. Thus, AUDPC fluctuations were indeed shifted compared with those of copiotrophic CFU, as observed visually.

Soil chemical properties. The soil chemical properties in two experiments had similar variations after incorporation of organic
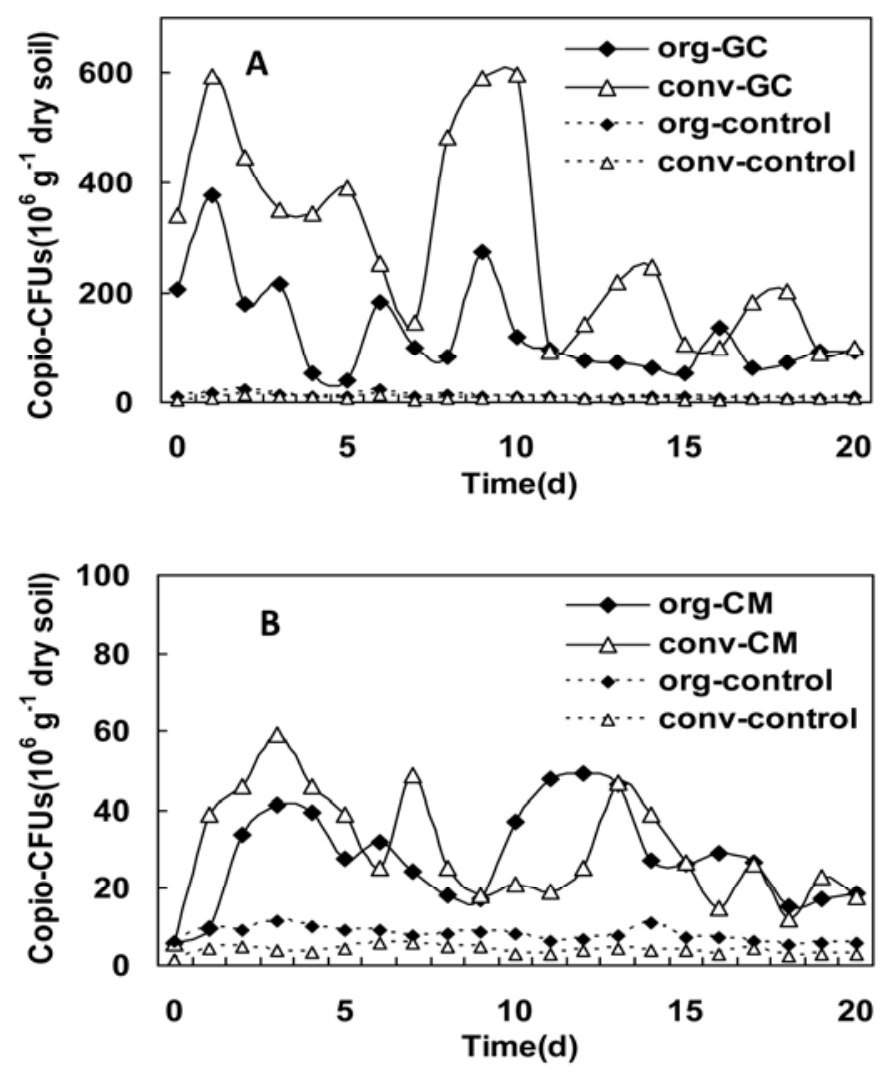

Fig. 3. Daily changes in copiotrophic CFU in organic (org) and conventional (conv) soils. A, soils with or without grass clover (GC) and $\mathbf{B}$, soils with or without composted manure (CM).

TABLE 3. Cross-correlations (0.05 significance level) between area under disease progress curve (AUDPC) and CFU in organic (org) and conventional (conv) soils after the incorporation of grass-clover (GC) or composted manure (CM)

\begin{tabular}{llcc}
\hline & & \multicolumn{2}{c}{ AUDPC } \\
\cline { 3 - 4 } Variable & Treatment & CCF & Lag $^{\mathrm{a}}$ \\
\hline CFU & Org-GC & 0.484 & -4 \\
& Conv-GC & 0.492 & -2 \\
& Org-CM & 0.464 & 3 \\
& Conv-CM & 0.484 & 2 \\
\hline
\end{tabular}

${ }^{\mathrm{a}} \mathrm{Lag}$ is the number of days one series is shifted compared with another series. Lag $<0$ means that the variable indicated in the leftmost column (i.e., first variable) leads the variable indicated in the top row; Lag $>0$ means that the variable indicated in the leftmost column follows the variable indicated in the top row with $[\mathrm{Lag}]$ number of days. materials, and significant changes were always observed in the initial 7 days (Figs. 4 and 5). Additions of organic materials increased $\mathrm{pH}$ levels and reached the first peak after 2 days (Fig. 4). In the following 5 days, $\mathrm{pH}$ dropped continuously to the initial levels and no significant fluctuations were observed after the first

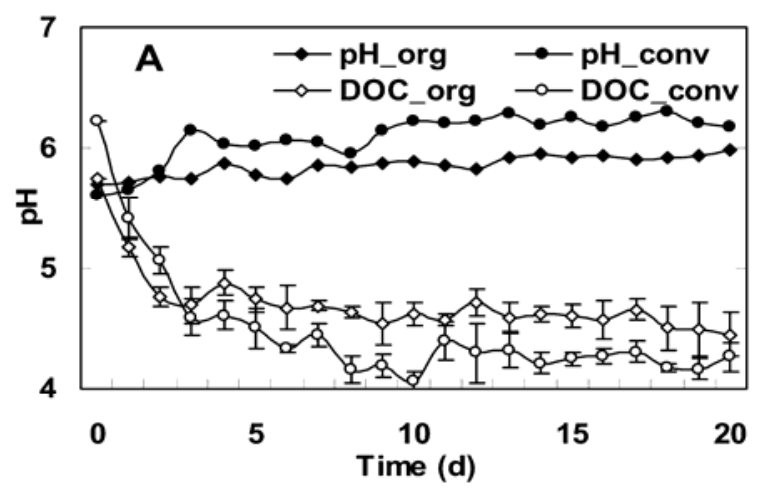

1400

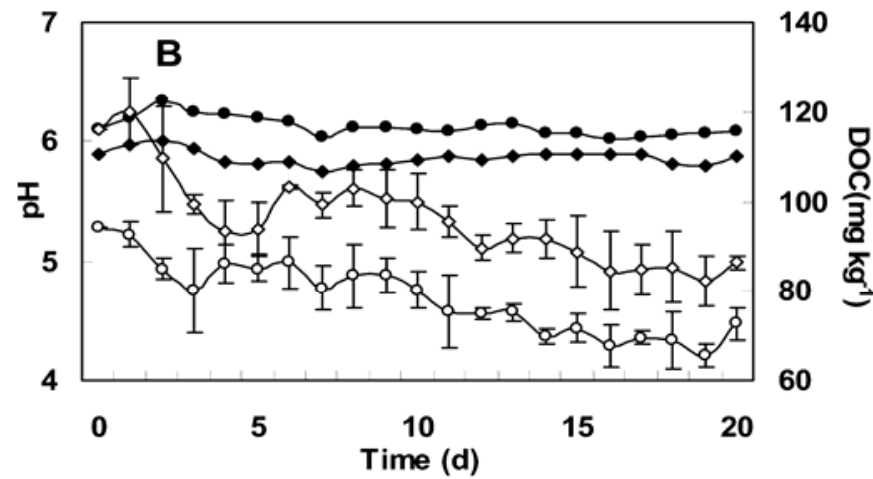

Fig. 4. Daily changes in $\mathrm{pH}$ value and concentrations of dissolved organic carbon (DOC) in organic (org) and conventional (conv) soils after incorporation of $\mathbf{A}$, grass-clover or $\mathbf{B}$, composted manure.
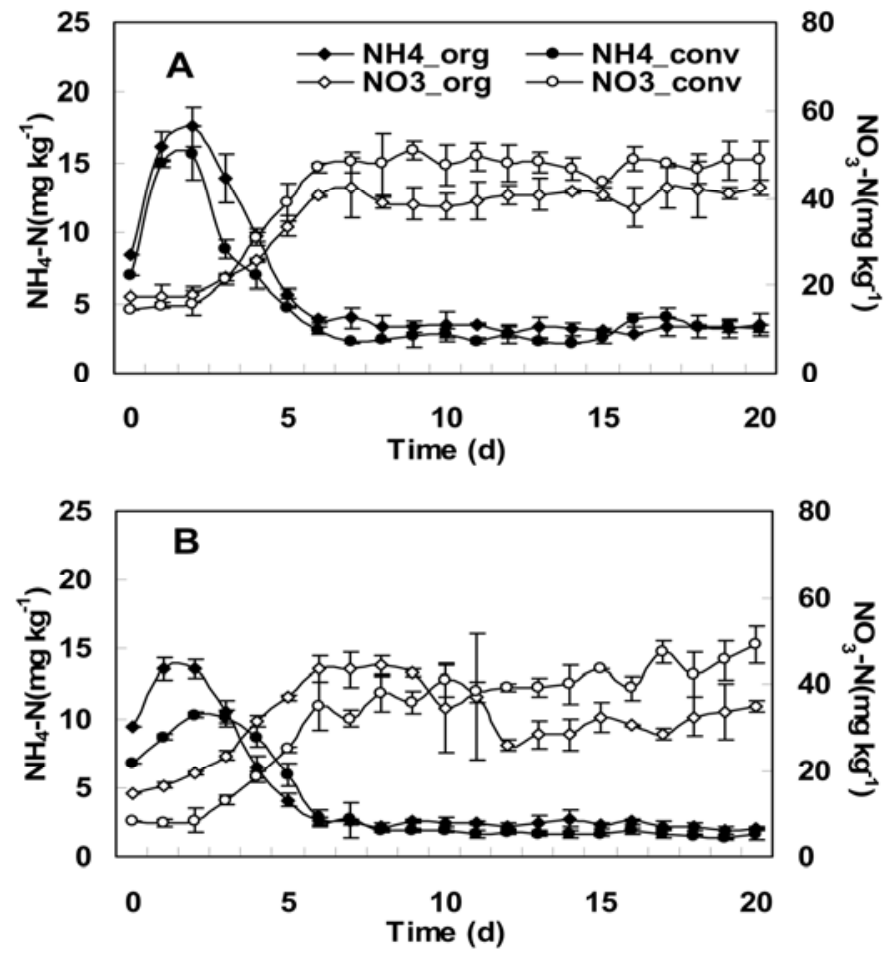

Fig. 5. Daily changes in concentrations of $\mathrm{NH}_{4}-\mathrm{N}$ and $\mathrm{NO}_{3}-\mathrm{N}$ in organic (org) and conventional (conv) soils after incorporation of $\mathbf{A}$, grass-clover or $\mathbf{B}$, composted manure. 
peak. The DOC contents increased 10 and 2 times after incorporation of GC and CM, respectively (Fig. 4) into soils. DOC concentrations increased immediately after organic matter incorporation, then declined sharply in the following 5 days and continued to decrease with very weak fluctuations until the end of the experiments. The decline of DOC in GC-amended soils was much more precipitous than in $\mathrm{CM}$-amended soils, probably because more stable organic matter existed in CM. Nonamended soils had considerably smaller changes in $\mathrm{pH}$ and DOC over time: $\mathrm{pH}$ in control series changed within 5.5 to 5.6 and 5.2 to 5.4 in the spring and summer experiment, respectively; the ranges of DOC contents in organic and conventional soils were 80 to 88 and 63 to $69 \mathrm{mg} \mathrm{kg}^{-1}$, respectively, in the spring experiment, and 66 to 73 and 44 to $49 \mathrm{mg} \mathrm{kg}^{-1}$, respectively, in the summer experiment.

The $\mathrm{NH}_{4}-\mathrm{N}$ concentrations increased immediately after addition of organic materials and reached a maximum on the second day (Fig. 5). The $\mathrm{NH}_{4}-\mathrm{N}$ contents declined precipitously in the following 5 days, and no fluctuations were observed after the first peak. There were no significant variations for $\mathrm{NO}_{3}-\mathrm{N}$ concentrations in amended soils during the first 2 days but $\mathrm{NO}_{3}-\mathrm{N}$ started to increase when $\mathrm{NH}_{4}-\mathrm{N}$ concentrations started to drop because of nitrification (Fig. 5). There were comparatively lower changes in $\mathrm{NH}_{4}-\mathrm{N}$ and $\mathrm{NO}_{3}-\mathrm{N}$ in control treatments over time: $\mathrm{NH}_{4}-\mathrm{N}$ changed within the range of 1.6 to $4.0 \mathrm{mg} \mathrm{kg}^{-1}$ for control treatments in the spring experiment and 1.0 to $2.5 \mathrm{mg} \mathrm{kg}^{-1}$ in the summer experiment; in nonamended soils, changes in $\mathrm{NO}_{3}-\mathrm{N}$ ranged between 5 to 15 and 10 to $20 \mathrm{mg} \mathrm{kg}^{-1}$ in the spring and summer experiment, respectively.

There were no significant wavelike oscillations in soil chemical properties after the initial peak, so that the fluctuations in AUDPC of pathogen infection and bacterial populations could not be attributed to changes of these chemical properties. Indeed, none of the $\mathrm{pH}, \mathrm{DOC}$, and $\mathrm{NH}_{4}-\mathrm{N}$ contents had significant correlations with AUDPC data. Daily changes of AUDPC were only correlated with $\mathrm{NO}_{3}{ }^{-}-\mathrm{N}$ when AUDPC data were shifted forward 5 days in GC-amended organic soil and 6 days in CM-amended conventional soil (Table 4). However, the fluctuations in CFU were always cross-correlated with changes in chemical variables in amended soils with a time differences of 1 to 2 days (Table 4).

\section{DISCUSSION}

For the first time, we demonstrated significant wavelike oscillations in the extent of infection of sugar beet by a plant pathogen (P. ultimum) over time after a disturbance of the soil by incorporation of fresh plant material or composted manure. The extent of infection was expressed as AUDPC in successive bioassays initiated daily after the disturbance was applied to unplanted soil, and it was assumed that AUDPC reflected the inoculum or infection potential of $P$. ultimum at the time of planting of the beet seed. Previously, wavelike distributions of infections by $P$. ultimum and Rhizoctonia solani were observed along roots of wheat (40). In that case, exudation from the root tip and sloughed-off root cap cells were considered the disturbing factor in bulk soil when the root tip arrived. Oscillations in time were inferred from the observed oscillations in space but, in this article, we showed that temporal oscillations in infections do indeed occur.

For the first time, we also demonstrated that the periods of the oscillations in AUDPC in amended soils were similar to those of bacterial populations over time but that the phase had shifted. This result was similar to the phase shift between bacterial populations and Pythium spp. infections observed along wheat roots (40). This indicates that the responses of $P$. ultimum and copiotrophic bacteria to a nutrient pulse were similar but their reaction speeds may have been different. Ellis et al. (10) found similar nutrient requirements for $P$. ultimum and Pseudomonas fluorescens 54/96, which is a well-known copiotrophic organism (11). Indeed, Pythium spp. and copiotrophic bacteria are both r-strategists, which have a faster response to disturbances than $\mathrm{k}$-strategists $(23,38)$. The shift in phase indicates that there was competition between Pythium ultimum and copiotrophic bacteria. In the organic soil amended with GC residues and the conventional soil amended with CM, the shift was approximately half as long as the period (Table 2), so that the oscillations were in opposite direction (Fig. 2A and D), indicating that P. ultimum could infect only after copiotrophic populations had subsided. In the conventional soil amended with GC and the organic soil amended with CM, the shift was one-quarter to one-third as long as the period, so that the oscillations in bacterial populations and AUDPC followed each other more closely (Fig. 2B and C). The reason for this difference in shift time is not clear.

The maxima in bacterial populations appeared earlier than those in AUDPCs in GC-amended soils whereas, in CM-amended soils, oscillations of CFU followed AUDPC fluctuations, suggesting that concentrations of available carbon and nitrogen in organic amendments might influence the pioneer group of competition between pathogens and bacteria. The GC-amended soil had higher concentrations of available carbon and nitrogen than the $\mathrm{CM}$-amended soils immediately after incorporation of the amendments, and copiotrophic bacteria proliferated faster than $P$. ultimum in GC-amended soils. In the CM-amended soils, the lower concentrations of readily available carbon and nitrogen might not have supported the rapid reproduction of bacteria immediately and, consequently, copiotrophic bacteria were out competed by $P$. ultimum. Alternatively, the rapid growth of bacteria in GCamended soil resulted initially in such high ammonium levels that these might have been toxic to $P$. ultimum, so that infection was initially reduced in both organic and conventional GC-amended soils. Ammonia was shown earlier to reduce survival of Pythium spp. so that Pythium disease could be controlled (21).

TABLE 4. Values of cross-correlation functions (0.05 significance levels) among chemical variables, area under disease progress curve (AUDPC), and CFU after incorporation of grass-clover (GC) or composted manure (CM) into organic (org) and conventional (conv) soils

\begin{tabular}{|c|c|c|c|c|c|c|c|c|c|}
\hline \multirow[b]{2}{*}{ Variable } & \multirow[b]{2}{*}{ Treatment } & \multicolumn{2}{|c|}{$\mathrm{NO}_{3}-\mathrm{N}$} & \multicolumn{2}{|c|}{$\mathrm{NH}_{4}-\mathrm{N}$} & \multicolumn{2}{|c|}{$\mathrm{pH}$} & \multicolumn{2}{|c|}{ Dissolved organic carbon } \\
\hline & & $\mathrm{CCF}$ & Lag $^{\mathrm{a}}$ & $\mathrm{CCF}$ & Lag & $\mathrm{CCF}$ & Lag & $\mathrm{CCF}$ & Lag \\
\hline \multirow[t]{3}{*}{ AUDPC } & Org-GC & 0.646 & -5 & ns & $\ldots$ & ns & $\ldots$ & ns & $\ldots$ \\
\hline & Conv-GC & $\mathrm{ns}$ & $\ldots$ & $\mathrm{ns}$ & $\ldots$ & $\mathrm{ns}$ & $\ldots$ & ns & $\ldots$ \\
\hline & Conv-CM & 0.512 & -6 & $\mathrm{~ns}$ & $\ldots$ & $\mathrm{ns}$ & $\ldots$ & $\mathrm{ns}$ & $\ldots$ \\
\hline \multirow{2}{*}{$\mathrm{CFU}$} & Org-GC & 0.716 & -1 & -0.713 & 0 & -0.552 & -1 & 0.649 & -1 \\
\hline & Conv-GC & 0.464 & -1 & -0.514 & -2 & -0.651 & -1 & 0.610 & -1 \\
\hline
\end{tabular}

${ }^{\text {a }}$ Lag is the number of days one series is shifted compared with another series. Lag $<0$ means that the variable indicated in the leftmost column (i.e., first variable) leads the variable indicated in the top row; Lag $>0$ means that the variable indicated in the leftmost column follows the variable indicated in the top row with [Lag] number of days; $\mathrm{ns}=$ not significant. 
However, taking the whole time series into account, the changes in $\mathrm{NH}_{4}-\mathrm{N}$ and $\mathrm{NO}_{3}-\mathrm{N}$ concentrations, as well as $\mathrm{pH}$ and DOC, did not seem to influence the fluctuation in P. ultimum AUDPCs because there were no significant cross correlations. In previous studies, chemical variables associated with organic matter decomposition were considered to affect growth and death of Pythium spp. directly $(1,3,27)$. However, the chemical variables in those studies were measured only occasionally, so that cross correlations over time could not be calculated. Although the daily soil chemical measurements in this study were not significantly cross-correlated with AUDPCs, they were cross-correlated with bacterial populations, and were likely the result of increases and decreases in bacterial metabolic activities and growth rather than the cause of the oscillations in bacterial populations.

Soilborne plant pathogens have frequently been reported to be suppressed after addition of organic amendments $(14,29)$, and this suppression was often associated with competition or antagonism by bacteria $(4,19,35)$. In the research reported here, $P$. ultimum damping-off did not simply decrease when daily observations were made after incorporation of organic materials into soils; however, the infection rates declined and increased with significant harmonic oscillations. Variations in pathogen infections with time had been published before $(7,24,34,37)$ but temporal wavelike patterns of pathogen infections had not been proven statistically or noted by the authors, partially because observations were not made frequently enough. Considering the occurrence of oscillations in bacterial populations and infections by soilborne pathogens (40; this article), it can now be understood why amendments with organic materials, including compost, sometimes resulted in increased rather than decreased damping-off depending on the maturity level of the compost used and the time elapsed between incorporation of the material and planting of a crop $(17,24)$. More research is needed to determine how long farmers need to wait after incorporation of compost or a cover crop before planting the next crop but the results presented here suggest that this time interval may need to be several weeks, depending on the kind of amendment and the temperature (which affects the decomposition rate and amplitudes and extinction time of the oscillations).

In addition to these practical implications of our research, the discovery of oscillations in inoculum or infection potential also has broader implications. Higher incidences of diseases in a soil system are indicative of an unhealthy ecosystem (9). Ecosystem health could be measured by resistance and resilience of the system after a disturbance, expressed by the amplitudes and dampening period of fluctuations in biological populations $(16,38)$. In our experiments, the amplitudes and frequencies in fluctuations of pathogen infections and copiotrophic CFU were always smaller in amended organic soil than in amended conventional soil. Soil in organically managed farms has been considered to be a stable ecosystem with resistance to a perturbation and more resilience $(41,42)$. Long-term use of chemical fertilizer and pesticides and frequent cultivation reduces bacterial diversities and competition in conventional soil (41), allowing fast-growing bacteria to reach a higher biomass after a disturbance and return to a steady state more slowly. Furthermore, higher microbial activity and larger bacterial diversities in organic soils could result in stronger suppressive abilities to Pythium damping-off $(4,5,18,43)$. In our study, the amended organic soils had higher microbial activity and microbial diversity and more limited microbial oscillations than amended conventional soils (unpublished data), resulting in lower AUDPC ratios in the organically managed soils. These results supported the notion that organic soils are healthier than soils from conventional farms $(37,38)$.

In conclusion, disease incidence by $P$. ultimum, as measured by AUDPC, oscillated after nutrient impulses into soils, similar to copiotrophic bacteria. Our observations create an opportunity to detect competitive or antagonistic bacteria of plant pathogens in soil at particular times relative to a disturbance, which is useful for the development of biological control of plant disease. Moreover, indicators for the health status of a soil, including disease suppressiveness, could be calculated based on the harmonic oscillations of plant pathogens and bacteria after a disturbance (31).

\section{ACKNOWLEDGMENTS}

This work was supported by Asia-Link Project "Organic Farming: ethical, economic, technical and scientific aspects in a global perspective" CN/ASIA-LINK/028 (108-962), postdoctoral fellowship no. 047.019.010 from NWO for A. Khodzhaeva, NWO-Russia collaborative grant no. 047.017.011 to A. H. C. van Bruggen and A. M. Semenov, and the National Natural Science Foundation of China (40871101). We thank A. Siepel for his help with selection and sampling of the soils, D. Volker and O. de Vos for helping us to prepare the experiments, and H. Halm for carrying out the soil chemical analyses.

\section{LITERATURE CITED}

1. Boehm, M. J., Madden, L. V., and Hoitink, H. A. J. 1993. Effect of organic matter decomposition level on bacterial species diversity and composition in relationship to Pythium damping-off severity. Appl. Environ. Microbiol. 59:4171-4179.

2. Campbell, C. L., and Madden, L. V. 1990. Page 532 in: Introduction to Plant Disease Epidemiology. Wiley-Interscience, New York.

3. Charest, M., Beauchamp, C. J., and Antoun, H. 2005. Effects of the humic substances of de-inking paper sludge on the antagonism between two compost bacteria and Pythium ultimum. FEMS Microbiol. Ecol. 52:219-227.

4. Chen, W., Hoitink, H. A. J., and Madden, L. V. 1988. Microbial activity and biomass in container media for predicting suppressiveness to damping-off caused by Pythium ultimum. Phytopathology 78:1447-1450.

5. Craft, C. M., and Nelson, E. B. 1996. Microbial properties of composts that suppress damping-off and root rot of creeping bentgrass caused by Pythium graminicola. Appl. Environ. Microbiol. 62:1550-1557.

6. Culman, S. W., Duxbury, J. M., Lauren, J. G., and Thies, J. E. 2006. Microbial community response to soil solarization in Nepal's rice-wheat cropping system. Soil Biol. Biochem. 38:3359-3371.

7. Descalzo, R. C., Punja, Z. K., Lévesque, C. A., and Rahe, J. E. 1998. Glyphosate treatment of bean seedlings causes short-term increases in Pythium populations and damping off potential in soils. Appl. Soil Ecol. 8:25-33.

8. de Vos, O. J., and van Bruggen, A. H. C. 2001. Soil microbial composition as affected by grass-clover mixture incorporation in the soil. ISME-9, P17.077, Amsterdam,

9. Doran, J. W., and Zeiss, M. R. 2000. Soil health and sustainability: Managing the biotic component of soil quality. Appl. Soil Ecol. 15:3-11.

10. Ellis, R. J., Timms-Wilson, T. M., Beringer, J. E., Rhodes, D., Renwick, A., Stevenson, L., and Bailey, M. J. 1999. Ecological basis for biocontrol of damping-off disease by Pseudomonas fluorescens 54/96. J. Appl. Microbiol. 87:454-463.

11. Gandolfi, I., Sicolo, M., Franzetti, A., Fontanarosa, E., Santagostino, A., and Bestetti, G. 2010. Influence of compost amendment on microbial community and ecotoxicity of hydrocarbon-contaminated soils. Bioresour. Technol. 101:568-575.

12. Garbeva, P., van Veen, J. A., and van Elsas, J. D. 2004. Assessment of the diversity, and antagonism towards Rhizoctonia solani AG3, of Pseudomonas species in soil from different agricultural regimes. FEMS Microbiol. Ecol. 47:51-64. Lit. cite 12 is not cited in the text. Please indicate where it belongs.

13. Gelsomino, A., and Cacco, G. 2006. Compositional shifts of bacterial groups in a solarized and amended soil as determined by denaturing gradient gel electrophoresis. Soil Biol. Biochem. 38:91-102.

14. Ghini, R., Patrício, F. R. A., Bettiol, W., de Almeida, I. M. G., and de Maia, A. H. N. 2007. Effect of sewage sludge on suppressiveness to soilborne plant pathogens. Soil Biol. Biochem. 39:2797-2805.

15. Gorbenko, A., and Kryshev, I. I. 1985. Page 143 in: Statistical Analysis of Dynamics of Microorganisms in Marine Ecosystems. Naukova Dumka, Kiev, Ukraine.

16. Griffiths, B. S., Bonkowski, M., Royc, J., and Ritz, K. 2001. Functional stability, substrate utilisation and biological indicators of soils following environmental impacts. Appl. Soil Ecol. 16:49-61.

17. Grünwald, N. J., Hu, S., and van Bruggen, A. H. C. 2000. Short-term cover crop decomposition in organic and conventional soils: Characterization of soil $\mathrm{C}, \mathrm{N}$, microbial and plant pathogen dynamics. Eur. J. Plant Pathol. 106:37-50. 
18. Hiddink, G. A., van Bruggen, A. H. C., Termorshuizen, A. J., Raaijmakers J. M., and Semenov, A. V. 2005. Effect of organic management of soils on suppressiveness to Gaeumannomyces graminis var. tritici and its antagonist, Pseudomonas fluorescens. Eur. J. Plant Pathol. 113:417-435.

19. Hoitink, H. A. J., and Boehm, M. J. 1999. Biocontrol within the contest of soil microbial communities: A substrate-dependent phenomenon. Annu. Rev. Phytopathol. 37:427-446.

20. Hoitink, H. A. J., and Fahy, P. C. 1986. Basis for the control of soilborne plant pathogens with composts. Annu. Rev. Phytopathol. 24:93-114.

21. Howell, C. R., Beier, R. C., and Stipanovic, R. D. 1988. Production of ammonia by Enterobacter cloacae and its possible role in the biological control of Pythium preemergence damping-off by the bacterium. Phytopathology 78:1075-1078.

22. Jenkins, G. M., and Watts, D. G. 1968. Page 525 in: Spectral Analysis and its Applications. Holden-Day, San Francisco.

23. Kozdrój, J., and van Elsas, J. D. 2000. Response of the bacterial community to root exudates in soil polluted with heavy metals assessed by molecular and cultural approaches. Soil Biol. Biochem. 32:1405-1417.

24. Leon, M. C. C., Stone, A., and Dick, R. P. 2006. Organic soil amendments: Impacts on snap bean common root rot (Aphanomyces euteiches) and soil quality. Appl. Soil Ecol. 31:199-210.

25. Litterick, A. M., Harrier, L., Wallace, P., Watson, C. A., and Wood, M., 2004. The role of uncomposted materials, composts, manures, and compost extracts in reducing pest and disease incidence and severity in sustainable temperate agricultural and horticultural crop production-a review. Crit. Rev. Plant Sci. 23:453-479.

26. Liu, B., Gumpertz, M. L., Hu, S. J., and Ristaino, J. B. 2007. Long-term effects of organic and synthetic soil fertility amendments on soil microbial communities and the development of southern blight. Soil Biol. Biochem. 39:2302-2316

27. Loffredo, E., Berloco, M., and Senesi, N. 2008. The role of humic fractions from soil and compost in controlling the growth in vitro of phytopathogenic and antagonistic soil-borne fungi. Ecotoxicol. Environ. Saf. 69:350-357.

28. Pérez-Piqueres, A., Edel-Hermann, V., Alabouvette, C., and Steinberg, C. 2006. Response of soil microbial communities to compost amendments. Soil Biol. Biochem. 38:460-470.

29. Postma, J., Schilder, M. T., Bloem, J., and van Leeuwen-Haagsma, W. K. 2008. Soil suppressiveness and functional diversity of the soil microflora in organic farming systems. Soil Biol. Biochem. 40:2394-2406.

30. Rapport, D. J. 1995. Ecosystem health—more than a metaphor. Environ. Values 4:287-309.

31. Semenov, A. M., van Bruggen, A. H. C., Bubnov, I. A., and Semenova, E. V. 2009. The method of determination of parameter of health in samples of soil, composts and other solid substrates. Registration number of RUSPATENT: 2009130742/12(042941). Date of registration: 12.08.2009.

32. Semenov, A. M., van Bruggen, A. H. C., and Zelenev, V. V. 1999. Moving waves of bacterial populations and total carbon along roots of wheat. Microbiol. Ecol. 37:116-128

33. Shumway, R. H. 1988. Applied Statistical Time Series Analysis. PrenticeHall, Englewood Cliffs, NJ.

34. Suffert, F., and Cuibert, M. 2007. The ecology of a Pythium community in relation to the epidemiology of carrot cavity spot. Appl. Soil Ecol.
35:488-501

35. Termorshuizen, A. J., van Rijn, E., van der Gaag, D. J., Alabouvette, C., Chen, Y., Lagerlöf, J., Malandrakis, A. A., Paplomatas, E. J., Rämert, B., Ryckeboerg, J., Steinbergc, C., and Zmora-Nahumd, S. 2006. Suppressiveness of 18 composts against 7 pathosystems: Variability in pathogen response. Soil Biol. Biochem. 38:2461-2477.

36. Toyota, K., and Kuninaga, S. 2006. Comparison of soil microbial community between soils amended with or without farmyard manure. Appl. Soil Ecol. 33:39-48.

37. van Bruggen, A. H. C., and Semenov, A. M. 1999. A new approach to the search for indicators of root disease suppression. Australas. Plant Pathol. 28:4-10.

38. van Bruggen, A. H. C., and Semenov, A. M. 2000. In search of biological indicators for soil health and disease suppression. Appl. Soil Ecol. 15:1324.

39. van Bruggen, A. H. C., Semenov, A. M., van Diepeningen, A. D., de Vos, O. J., and Blok, W. J. 2006. Relation between soil health, wave-like fluctuations in microbial populations, and soil-borne plant disease management. Eur. J. Plant Pathol. 115:105-122.

40. van Bruggen, A. H. C., Semenov, A. M., and Zelenev, V. V. 2002. Wavelike distributions of infections by an introduced and naturally occurring root pathogen along wheat roots. Microbiol. Ecol. 44:30-38.

41. van Diepeningen, A. D., de Vos, O. J., Korthals, G. W, and van Bruggen, A. H. C. 2006. Effects of organic versus conventional management on chemical and biological parameters in agricultural soils. Appl. Soil Ecol. 31:120-135.

42. van Diepeningen, A. D., de Vos, O. J., Zelenev, V. V., Semenov, A. M., and van Bruggen, A. H. C. 2005. DGGE fragments oscillate with or counter to fluctuations in cultivable bacteria along wheat roots. Microb.iol Ecol. 50:506-517.

43. van Os, G. J., and van Ginkel, J. H. 2001. Suppression of Pythium root rot in bulbous Iris in relation to biomass and activity of the soil microflora. Soil Biol. Biochem. 33:1447-1454.

44. Veeken, A. H. M., Blok, W. J., Curcia, F., Coenen, G. C. M., Termorshuizenb, A. J., and Hamelers, H. V. M. 2005. Improving quality of composted biowaste to enhance disease suppressiveness of compost-amended, peat-based potting mixes. Soil Biol. Biochem. 37:2131-2140.

45. Zelenev, V. V., Berkelmans, R., van Bruggen, A. H. C., Bongers, T., and Semenov, A. M. 2004. Daily changes in bacterial-feeding nematode populations oscillate with similar periods as bacterial populations after a nutrient impulse in soil. Appl. Soil Ecol. 26:93-106.

46. Zelenev, V. V., van Bruggen, A. H. C., Leffelaar, P. A., Bloem, J., and Semenov, A. M, 2006. Oscillating dynamics of bacterial populations and their predators in response to fresh organic matter added to soil: The simulation model 'BACWAVE-WEB'. Soil Biol. Biochem. 38:1690-1711.

47. Zelenev, V. V., van Bruggen, A. H. C., and Semenov, A. M. 2000. "BACWAVE", a spatial-temporal model for traveling waves of bacterial populations in response to a moving carbon source in soil. Microbiol. Ecol. 40:260-272.

48. Zelenev, V. V., van Bruggen, A. H. C., and Semenov, A. M. 2005. Shortterm wavelike dynamics of bacterial populations in response to nutrient input from fresh plant residues. Microbiol. Ecol. 49:83-93. 